\title{
Authigenic titanite in paleosols indicates elevated temperatures and low atmospheric $\mathrm{CO}_{2}$ levels
}

\author{
Alexey A. Novoselov ${ }^{1 *}$, Dailto Silva ${ }^{2}$, Carlos \\ ROBERTO DE SOUZA FILHO ${ }^{3}$ \\ ${ }^{1}$ Institute of Applied Economic Geology, Universidad de \\ Concepción, Concepción, 4030400, Chile, \\ (*correspondence: Alexey.Novoselov@udec.cl) \\ ${ }^{2}$ Institute of Geosciences, University of Campinas, PO Box \\ 6152, Campinas, SP 13083-970, Brazil, \\ (dailto@unicamp.br) \\ ${ }^{3}$ Institute of Geosciences, University of Campinas, PO Box \\ 6152, Campinas, SP 13083-970, Brazil, \\ (beto@unicamp.br)
}

Secondary titanite forms during weathering of Paraná basalts under hot and humid tropical climatic conditions in the southeast of Brazil [1]. The grains of up to $170 \mu \mathrm{m}$ deposit together with Fe-rich clay minerals, chalcedony and barite. There are no carbonate minerals in the weathering profile. In contrast to titanites of magmatic and hydrothermal origins, the found specimens represent the elevated $\mathrm{Al}_{2} \mathrm{O}_{3}$, $\mathrm{Eu} / \mathrm{Eu}^{*}$, and $\mathrm{La}_{\mathrm{N}} / \mathrm{Yb}_{\mathrm{N}}$ and low abundances of $\mathrm{Y}, \Sigma \mathrm{REE}, \mathrm{Zr}$, Th, and U. Using methods of geochemical modeling, we reveal that those titanites are genetically related with dissolution of plagioclase and precipitate from oxygen-free and high-pH pore fluids. Calcite accumulates in the course of weathering of basaltic rocks at moderate climatic conditions. The transition from calcite to titanite corresponds to the mean ambient temperature of $\sim 25^{\circ} \mathrm{C}$. This thermodynamically defined limit should be higher under $\mathrm{CO}_{2}$-rich atmosphere. The presence of authigenic titanite in ancient paleosols formed on Earth and other planets may indicate the hot and wet environmental conditions, low $\mathrm{pCO}_{2}$, or reduced atmospheric composition.

[1] Novoselov et al. (2020) Geoscience Frontiers 11, https://doi.org/10.1016/j.gsf.2020.03.012. 